http://dx.doi.org/10.1590/1678-4162-9131

Arq. Bras. Med. Vet. Zootec., v.69, n.2, p.340-346, 2017

\title{
Acoustic radiation force impulse (ARFI) elastography of adrenal glands in healthy adult dogs
}

[Elastografia acoustic radiation force impulse (ARFI) das glândulas adrenais de cães adultos saudáveis]

\author{
S. Fernandez ${ }^{1}$, M.A.R. Feliciano ${ }^{1,3 *}$, S. Borin-Crivellenti ${ }^{2}$, L.Z. Crivellenti ${ }^{2}$, M.C. Maronezi ${ }^{1}$, A.P.R. \\ Simões ${ }^{1}$, P.D.A. Silva ${ }^{1}$, R.R. Uscategui ${ }^{1}$, N.R.N. Cruz ${ }^{1}$, A.E. Santana ${ }^{1}$, W.R.R. Vicente ${ }^{1}$ \\ ${ }^{1}$ Faculdade de Ciências Agrárias e Veterinárias - UNESP/Jaboticabal - Jaboticabal, SP \\ ${ }^{2}$ Universidade de Franca-UNIFRAN - Franca, SP \\ ${ }^{3}$ Universidade Federal do Recôncavo da Bahia - UFRB - Cruz das Almas, BA
}

\begin{abstract}
To describe the ARFI elastography in the evaluation of the adrenal glands in adult dogs, to evaluate the stiffness of adrenal parenchyma and to determine the qualitative and quantitative standards of the ARFI technique, which have not yet been described in veterinary medicine. Sixty adrenal glands from thirty healthy adult dogs were evaluated by B-mode and qualitative and quantitative ARFI elastography to assess the stiffness of healthy parenchyma and to determine the quality and quantity (shear velocity) standards of ARFI technique in body, cranial and caudal adrenal poles. Findings of ultrasonography evaluations were normal. Qualitative elastography showed that adrenal glands were not deformable and presented homogeneous middle-gray areas. The results of shear wave velocity were similar statically $(\mathrm{P}=$ 0.3087 ): 1) left adrenal $-1.42 \mathrm{~m} / \mathrm{s}$ for cranial polar, $1.31 \mathrm{~m} / \mathrm{s}$ for body region, and $1.71 \mathrm{~m} / \mathrm{s}$ for caudal polar; 2) right adrenal $-1.42 \mathrm{~m} / \mathrm{s}$ for cranial polar, $1.74 \mathrm{~m} / \mathrm{s}$ for body region and $1.63 \mathrm{~m} / \mathrm{s}$ for caudal pole. Quantitative and qualitative ARFI elastography of dogs' adrenal glands is feasible, well tolerated, easily implemented and may provide baseline data in the study of this structure to allow the use of ARFI.
\end{abstract}

Keywords: canine, adrenal, ultrasound

\section{RESUMO}

Objetivou-se descrever a técnica de elastografia ARFI na avaliação das glândulas adrenais em cães adultos, visando avaliar a rigidez do parênquima adrenal saudável e determinar os padrões qualitativos e quantitativos (velocidade de cisalhamento) da técnica ARFI, ainda não descritos em medicina veterinária. Sessenta glândulas adrenais de 30 cães adultos saudáveis foram avaliadas pela ultrassonografia modo $B$ e pela elastografia ARFI qualitativa e quantitativa para avaliar a rigidez do parênquima saudável e determinar a velocidade de cisalhamento e padrões qualitativos da ARFI no corpo, polos adrenais cranial e caudal. As características ultrassonográficas das glândulas foram normais. A elastografia qualitativa mostrou que glândulas adrenais não se apresentaram deformáveis e homogêneas (coloração cinza médio). Os resultados da velocidade de cisalhamento foram semelhantes ( $P=0,3087): 1$ ) adrenal esquerda $-1,42 \mathrm{~m} / \mathrm{s}$ para polo cranial, $1,31 \mathrm{~m} / \mathrm{s}$ para corpo e $1,71 \mathrm{~m} / \mathrm{s}$ para polo caudal; 2) adrenal direita - 1,42m/s para polo cranial, $1,74 \mathrm{~m} / \mathrm{s}$ para corpo e $1,63 \mathrm{~m} / \mathrm{s}$ para polo caudal. A elastografia quantitativa e qualitativa (ARFI) das glândulas adrenais de cães é uma ferramenta viável e facilmente implementada, podendo proporcionar valores padrão para o estudo dessa estrutura.

Palavras-chave: canino, adrenal, ultrassom

Recebido em 26 de abril de 2016

Aceito em 7 de julho de 2016

*Autor para correspondência (corresponding author)

E-mail: marcusfeliciano@yahoo.com.br 


\section{INTRODUCTION}

Currently, ultrasonographic exam of adrenal glands has become part of abdominal scanning of canine patients with suspected endocrine disease, enabling the identification of these structures, their ultrasonographic description (echogenicity and echotexture) and biometric measurements (Cook et al. 2014). This technique is described in the literature as a useful imaging modality in the diagnostic workup of canine patients with adrenal neoplasms of the cortex and medulla, hypoadrenocorticism or hyperadrenocorticism and aiding in differentiation of pituitarydependent hyperadrenocorticism (PDH) from adrenal-dependent hyperadrenocorticism (ADH) (Douglass et al. 1997; Choi et al. 2011; Chalus et al. 2013).

In addition to the abnormalities above mentioned, ultrasonography has assisted in the detection of incidental adrenal gland lesion (IAGL), also called incidentalomas, either in humans (Slapa et al. 2014) and animals (Cook et al. 2014), however the definitive diagnosis of these lesions remains a challenge for the ultrasound technique, requiring invasive methods for diagnosis. As an alternative for the diagnosis of IAGL, Slapa et al. (2015) have considered elastography as a potential and important technique for the suitable diagnosis and the differentiation of solid and cystic adrenal lesions in humans.

Elastography is a novel model of ultrasonographic technique able to access tissue elasticity through various methods, such as compression, acoustic radiation force impulse (ARFI) and real-time shear velocity or supersonic (RSV). In fact, ARFI elastography is the technique with greater reproducibility and which shows the best accuracy with less interobserver variation, when compared to others (Feliciano et al. 2014).

Previous studies showed that ARFI elastography is safe, non-invasive and provides both quantitative and qualitative measures of tissue stiffness through the generation of shear waves using radiation force impulse associated with a B-mode image in animals (Carvalho et al. 2015). Qualitative ARFI is able to provide an elastogram of the relative stiffness of the tissue where lighter areas represent the more deformable tissues (Feliciano et al. 2014). Quantitative study is related to the rigidity of the tissues, in which the velocity of propagation is capable of deforming the tissues, and higher velocity represents rigid tissues (Garcia et al. 2015).

The veterinary studies using this ARFI technique are recent and have been used to evaluate mammary tumors in female dogs (Feliciano et al. 2014), spleen, liver and kidneys of adult dogs (Holdsworth et al. 2014; Maronezi et al. 2015), splenic and renal tissue in felines (Feliciano et al. 2015a; Garcia et al. 2015) and prostate and testicles in canines and felines (Brito et al. 2015; Feliciano et al. 2015b). There are no reports of the use of this technique in the evaluation of the adrenal glands of animals.

Considering the recent applicability of ARFI method and the reports of this type of elastography in tissue evaluation of small animals, the present study aims to describe the technique of ARFI elastography in the evaluation of the adrenal glands in adult dogs, to evaluate the stiffness of healthy adrenal parenchyma and to determine the qualitative and quantitative (sheer velocity) standards of the ARFI technique, which have not yet been described in veterinary medicine.

\section{MATERIAL AND METHODS}

This study was conducted with the approval of the Animal Ethics and Welfare Committee of Faculdade de Ciências Agrárias e Veterinárias, UNESP - Universidade Estadual Paulista, Campus Jaboticabal, Brazil (protocol No $8547 / 15)$. The adrenal glands of 30 healthy adult dogs (60 adrenal glands in total), with range from 1 to 7 years of age (mean age $=4.0 \pm 1.44$ years), weighing between 2 to $15 \mathrm{~kg}($ mean $=8$. $5 \pm 3.19 \mathrm{~kg}$ ) and with corporal score of 6 (1 to 9) were selected for this study following a normal physical, hematological exam, biochemical profile (urea, creatinine, ALT, ALP, cholesterol, triglycerides, total protein and albumin).

Low-dose dexamethasone suppression test (LDDST) was performed in all dogs to demonstrate a normal hypothalamic-pituitaryadrenal axis (HPAA) sensitivity to negative glucocorticoid feedback. The LDDST was performed using $0.01-0.015 \mathrm{mg} / \mathrm{kg}$ 
dexamethasone sodium phosphate intravenously, and cortisol concentrations measured just before, and at 4 and 8 hours after dexamethasone administration typically fell below $1.4 \mathrm{mcg} / \mathrm{dL}$ $(20 \mathrm{nmol} / \mathrm{L})$ by 4 hours and remain at that level by 8 hours after dexamethasone administration (Gilor and Graves 2011).

After the animals were selected, the abdominal fur was shaved to allow the ultrasonographic exam. Before the exam, coupling gel was applied on the skin. The ultrasonography was performed by a single, experienced ultrasonographer. BMode ultrasonography was performed with a 9.0 $\mathrm{MHz}$ linear matrix transducer using ACUSON S2000/SIEMENS ultrasound equipment (Siemens, Munich, Germany). The echotexture (homogeneous or heterogeneous), echogenicity (hypoechoic, hyperechoic or mixed) of the parenchyma, size (length and width of the cranial and caudal pole) and contours and margins (regular or irregular) of the adrenal glands (left and right) were assessed and categorized in longitudinal section.

For the elastography, software for qualitative and quantitative analysis was compared using the ARFI method (Virtual Touch Tissue Quantification) and a $9.0 \mathrm{MHz}$ linear matrix transducer (Feliciano et al. 2014).

After performing B-mode ultrasonography, the qualitative ARFI technique was applied, resulting in the formation of grayscale images of the adrenal glands (left and right). The images were evaluated with specific focus on the presence of deformities, white areas (indicative of more elastic tissue that is less rigid, softer, and more deformable) and dark areas (more rigid, harder and non-deformable).

Quantitative evaluation was also performed after scanning the kidney with the B-mode ultrasound. The function for obtaining sheer velocity was activated, and the calliper was positioned in the adrenal glands; the fixed region of interest box dimensions were $10 \mathrm{~mm} \times 10 \mathrm{~mm}$. Six measurements in each position (body, caudal and cranial pole) of the adrenal (left and right) were obtained (with depth between 1.3 to $3.1 \mathrm{~cm}$ for adrenal glands) and used to determine sheer velocities (means and standard deviations [SD]).

Data were analyzed with the $R \circledast$ statistical software (R Foundation for Statistical Computing; Vienna, Austria). Data were submitted to analysis of variance (ANOVA), with a prior test for homogeneity of variances and normal distribution (Shapiro test, variance test), in a complete randomized experimental design. Spearman correlations were used to determine relationships between the variables studied. The significance for all tests was set at $5 \%$ ( $\mathrm{P}$ value $<0.05$ ). Results are presented as mean \pm standard deviation [SD].

\section{RESULTS}

Assessment of the adrenal glands in all dogs using B-mode ultrasound showed no abnormalities in echotexture (homogenous), echogenicity (hypoechoic in relation to adjacent fat) of the parenchyma, size (left adrenal $1.68 \pm 0.62 \mathrm{~cm}$ of length, $0.38 \pm 0.08 \mathrm{~cm}$ of width of the cranial pole and $0.44 \pm 0.07 \mathrm{~cm}$ of width of the caudal pole; right adrenal - $1.67 \pm 0.33 \mathrm{~cm}$ of length, $0.41 \pm 0.09 \mathrm{~cm}$ of width of the cranial pole and $0.48 \pm 0.11 \mathrm{~cm}$ of width of the caudal pole) and contours and margins (regulars) (Table 1). There was no significant difference between the size of left and right adrenal glands $(\mathrm{P}>0.05)$.

The qualitative and quantitative elastography of the adrenal glands in dogs could be performed without difficulty. On the basis of the qualitative elastography, the adrenal parenchyma is not deformable, has homogeneous appearance and presents middle-grey coloration (Figure 1).

Table 1. Assessment of the adrenal glands sizes using B-mode ultrasound. Length and width measurements from 60 adrenal glands are presented as mean \pm standard deviation.

\begin{tabular}{lccc} 
& \multirow{2}{*}{ Length $(\mathrm{cm})$} & \multicolumn{2}{c}{ Width $(\mathrm{cm})$} \\
\cline { 3 - 4 } & & Cranial Pole & Caudal Pole \\
\hline Left Adrenal Gland & $1.68 \pm 0.62$ & $0.38 \pm 0.08$ & $0.44 \pm 0.07$ \\
Right Adrenal Gland & $1.67 \pm 0.33$ & $0.41 \pm 0.09$ & $0.48 \pm 0.11$ \\
\hline
\end{tabular}




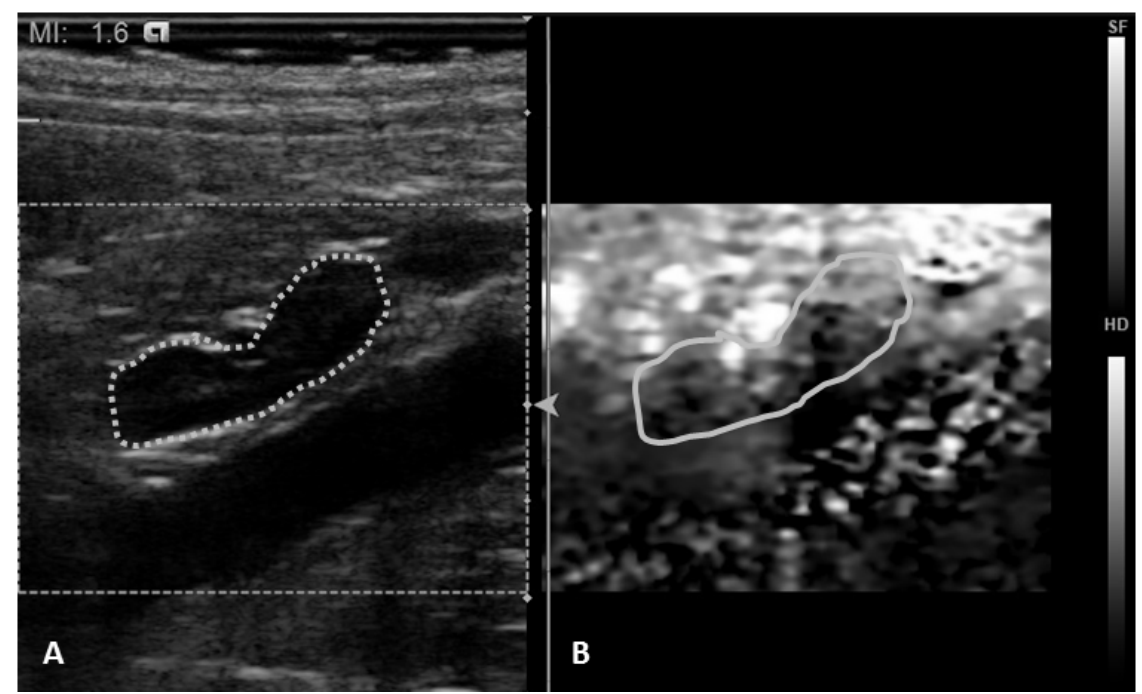

Figure 1. Ultrasound image of a canine adrenal during its qualitative ARFI elastography. (A) B-mode image of adrenal gland (dashed line) with normal echogenicity and echotexture; (B) elastographic image of adrenal gland (continuous line) with parenchyma was not deformable, homogeneous appearance and middle-grey coloration.

Using quantitative elastography, the mean sheer velocity values (Figure 2) were: 1) left adrenal $1.42 \mathrm{~m} / \mathrm{s}(95 \%$ confidence interval: $1.70-1.67$ $\mathrm{m} / \mathrm{s})$ for cranial pole, $1.31 \mathrm{~m} / \mathrm{s}(95 \%$ confidence interval: $0.72-1.91 \mathrm{~m} / \mathrm{s}$ ) for body region and $1.71 \mathrm{~m} / \mathrm{s}(95 \%$ confidence interval: $1.47-1.95$ $\mathrm{m} / \mathrm{s}$ ) for caudal pole; 2) right adrenal $-1.42 \mathrm{~m} / \mathrm{s}$ (95\% confidence interval: $1.11-1.74 \mathrm{~m} / \mathrm{s})$ for cranial pole, $1.74 \mathrm{~m} / \mathrm{s}(95 \%$ confidence interval: $1.23-2.25 \mathrm{~m} / \mathrm{s}$ ) for body region and $1.63 \mathrm{~m} / \mathrm{s}$ (95\% confidence interval: $1.34-1.91 \mathrm{~m} / \mathrm{s}$ ) for caudal pole. There was no significant difference between sheer velocity values from left and right adrenal glands and their evaluated portions in relation to the sheer velocity $(\mathrm{P}=0.3087)$.

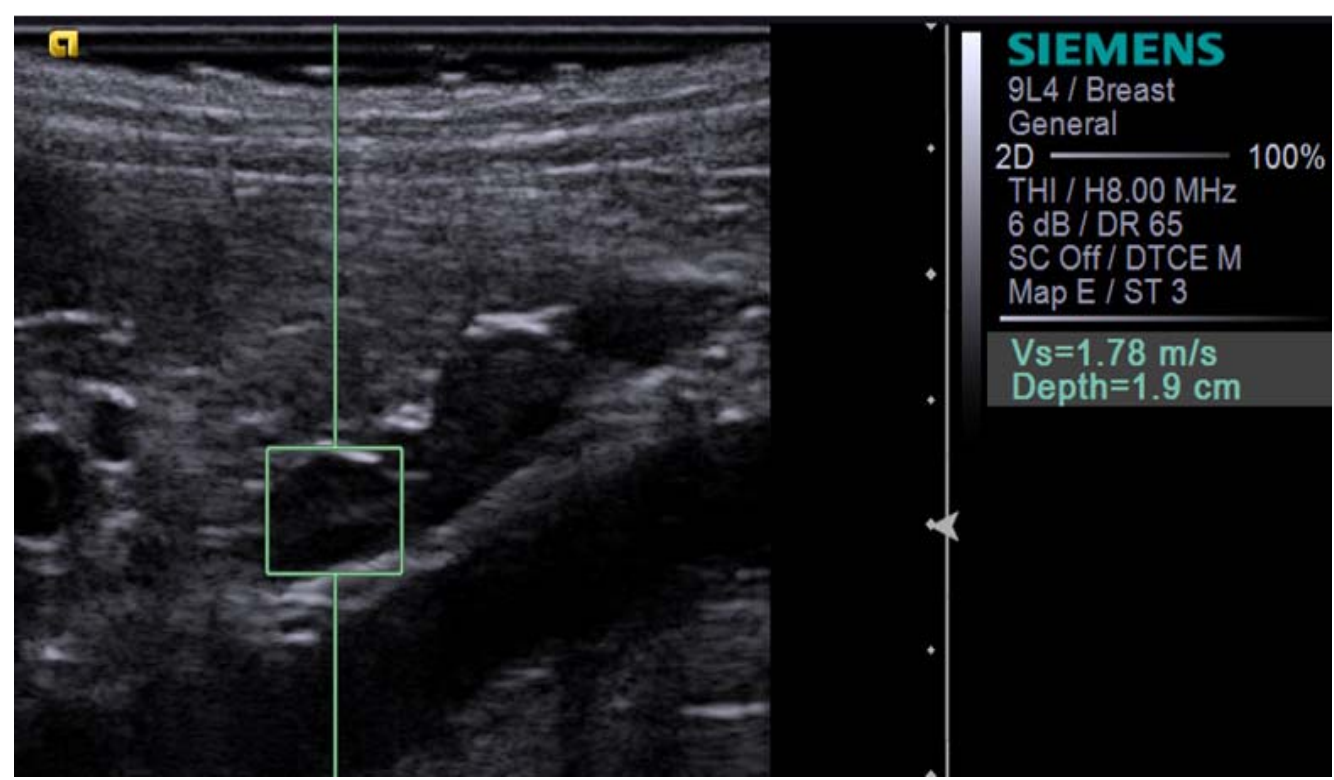

Figure 2. Ultrasound image of a canine adrenal during its quantitative ARFI evaluation with presence of calipter in cranial region and to obtain of the shear velocity. 
Sheer velocity and depth presented negative correlations, since sheer velocity has decreased in $0.3 \mathrm{~m} / \mathrm{s}$ for each centimetre added in the depth $(\mathrm{P}=0.02$, and $\mathrm{R} 2=0.3)$, and also decreased 0.26 $\mathrm{m} / \mathrm{s}$ for each centimetre added in gland size $(\mathrm{P}=$ 0.02 , and $\mathrm{R} 2=0.2$ )

\section{DISCUSSION}

Ultrasonography is the most used imaging modality for evaluation of adrenal glands in canines and the sonographic findings diagnose disorders that affect these glands; however, the absence of abnormal findings does not exclude the presence of adrenal disease (Soulsby et al. 2015), requiring the association with other diagnostic methods. These complementary methods are considered invasive and according to the latest consensus of American College of Veterinary Internal Medicine - ACVIM 2012 are not $100 \%$ effective (including endocrine tests), resulting in significant difficulty to obtain the correct diagnostic sensitivity and specificity (Behrend et al. 2013). This is the first study using ARFI technique in the evaluation of adrenal structures of dogs to achieve reference values for this technique, and the study of the stiffness in this ARFI technique can be used to increase the sensitivity and specificity of a correct diagnosis of adrenal alterations.

Some factors that decrease the accuracy of ultrasound technique to assess the adrenal glands of canines are: imaging methods are highly observer-dependent (poor reproducibility), meaning that measurements can depend on the expertise of the observer; the measurements vary according to biological variations such as age, sex and body weight; limited diagnosis and differentiation for incidental adrenal gland lesions (IAGL) (Mogicato et al. 2011; Cook et al. 2014); demonstrating the relevance of the introduction of new ultrasound techniques, such as elastography, to improve the accuracy of ultrasonographic examination of the adrenals.

The use of elastography for assessment of adrenals in humans is a recent and feasible technique for the evaluation of adrenal masses, demonstrating that it has the potential to differentiate malignant and benign lesions (Slapa et al. 2014). Currently, in veterinary, preliminary results from the ARFI elastographic evaluation of mammary neoplasms in female dogs demonstrated that malignancy was suggested by rigid and non-deformable tissue with high shearwave velocity (Feliciano et al. 2014). It is possible that adrenal abnormalities (e.g. neoplasms) may produce alterations that are detectable by ARFI elastography, and this may aid diagnosis of diseases in the future.

In the present study, the adrenal parenchyma consistently exhibited a rigid and homogenous tissue that was not easily deformable, suggesting that qualitative elastography could potentially be performed to detect altered intra-parenchymal areas (hard/soft or deformable/not deformable), specifically for detection and diagnosis of lesions incidental adrenal gland masses. IAGL with increased size $(>\neg 20 \mathrm{~mm}$ in maximum dimension) and vascular invasion may indicate the presence of malignant neoplasms in the canine adrenal detected by ultrasound exam, however, smaller lesions which do not show changes in echogenicity and echotexture may be undetectable by this imaging method (Cook et al. 2014). Considering that the adrenal abnormalities in dogs have different histopathological and tissue structures (e.g., neoplasia, hyperplasia, cysts and other), any modification on the tissue stiffness observed during the course of adrenal diseases in dogs may be effectively monitored with the ARFI imaging, increasing the accuracy of the ultrasonographic technique for detecting an array of splenic disorders in dogs.

The mean value of sheer velocity of adrenal portions of dogs provides quantitative and unpublished information about the rigidity of these normal tissues. In human patients, Slapa et al. (2014) observed a higher stiffness in neoplastic tissues when compared to hyperplastic and cystic tissues using quantitative elastography (these authors supersonic sheer wave elastography - supersonic). These quantitative values obtained by ARFI of the adrenal in dogs are the first described in literature and further studies in animals with adrenal disease should be performed to evaluate the applicability of the technique. Elastography has proven its applicability for assessment of mammary tissue of female dogs (Feliciano et al. 2014), in which high sheer rates (compared to healthy state mammary tissue) are related to a greater stiffness of mammary tissue and increased likelihood of malignancy. 
The effect of the animals' body length and width of the adrenal samples on the sheer velocity observed (decrease in $0.3 \mathrm{~m} / \mathrm{s}$ for each one centimeter added in the depth and decrease in $0.26 \mathrm{~m} / \mathrm{s}$ for each one centimeter added in gland size) has already been verified in previously study in veterinary for splenic evaluation Holdsworth et al. (2014). These authors observed the influence of some conditions on the splenic sheer velocity in dogs; there was an increase of $0.021 \mathrm{~m} / \mathrm{s}$ for every $1 \mathrm{~kg}$ increase in dogs' body weight and a decline by $0.197 \mathrm{~m} / \mathrm{s}$ for every $1 \mathrm{~cm}$ increase in depth. As noted in splenic elastography Holdsworth et al. (2014), it is necessary to conduct a study with animals of different breeds and corporal conformation to examine the interactions of these factors on the elastographic characteristics of the canine adrenal.

It is important to enhance some considerations observed during this study: 1) restless patients and faster breathing may hinder the acquisition of elastographic parameters. Although sedation has not been performed in this study, the animals were kept in quiet surroundings and with minimal restraint; 2) adequate number of animals were used which permitted the acquisition of relevant information to validate the technique; however, it is suggested that further studies with dogs of different breeds and with different ages and body conditions take place.

It is believed that after the standardization of the reference values and characteristics of tissue stiffness for the adrenal elastography in healthy dogs, the differences in values of shear velocity and abnormalities in qualitative findings from the damaged tissues can be evaluated for the applicability of ARFI elastography for differentiating benign and malignant adrenal injuries in dogs.

\section{CONCLUSION}

Quantitative and qualitative ARFI elastography of the adrenal glands in healthy adult dogs were easily implemented and may provide baseline data in the study of this structure to allow the future use of ARFI on clinical routine.

\section{ACKNOWLEDGEMENTS}

The authors thank FAPESP for research grant and young investigator scholarship (processes 2012/16635-2 and 2013/06443-1).

\section{REFERENCES}

BEHREND, E.N.; KOOISTRA, H.S.; NELSON, $\mathrm{R}$. et al. Diagnosis of spontaneous canine hyperadrenocorticism: 2012 ACVIM consensus statement (small animal). J. Vet. Intern. Med., v.2, p.1292-1304, 2013.

BRITO, M.B.S.; FELICIANO, M.A.R.; COUTINHO, L.N. et al. ARFI Elastography of healthy adults felines testes. Acta Sci. Vet., v.43, p.1303-1308, 2015.

CARVALHO, C.F.; CINTRA, T.C.F.; CHAMMAS, M.C. Elastography: principles and considerations for clinical research in veterinary medicine. J. Vet. Med. Anim. Health, v.7, p.99110, 2015.

CHALUS, T.; COMBES, A.; BEDU, A.S. et al. Ultrasonographic adrenal gland measurements in healthy yorkshire terriers and labrador retrievers. Anat. Histol. Embryol., v.42, p.57-64, 2013.

CHOI, J.; KIM, H.; YOON, J. Ultrasonographic adrenal gland measurements in clinically normal small breed dogs and comparison with pituitarydependent hyperadrenocorticism. J. Vet. Med. Sci., v.73, p.985-989, 2011.

COOK, A.K.; SPAULDING, K.A.; EDWARDS, J.F. Clinical findings in dogs with incidental adrenal gland lesions determined by ultrasonography: 151 cases (2007-2010). J. Am. Vet. Med. Assoc., v.244, p.1181-1185, 2014.

DOUGLASS, J.P.; BERRY, C.R.; JAMES, S. Ultrasonographic adrenal gland measurements in dogs without evidence of adrenal disease. Vet. Radiol. Ultrasound, v.38, p.124-130, 1997.

FELICIANO, M.A.R.; MARONEZI, M.C.; CRIVELLENTI, L.Z. et al. Acoustic radiation force impulse (ARFI) elastography of the spleen in healthy adult cats: a preliminary study. $J$. Small Anim. Pract., v.56, p.180-183, 2015a.

FELICIANO, M.A.R.; MARONEZI, M.C.; PAVAN, L. et al. ARFI elastography as complementary diagnostic method of mammary neoplasm in female dogs: preliminary results. $J$. Small Anim. Pract., v.55, p.504-508, 2014. 
FELICIANO, M.A.R.; MARONEZI, M.C.; SIMÕES, A.P.R. et al. Acoustic radiation force impulse elastography of prostate and testes of healthy dogs: preliminary results. J. Small Anim. Pract., v.56, p.320-324, 2015 b.

GARCIA, P.H.S.; FELICIANO, M.A.R.; CARVALHO, C.F. et al. Acoustic radiation force impulse (ARFI) elastography of kidneys in healthy adult cats: preliminary results. J. Small Anim. Pract., v.56, p.505-509, 2015.

GILOR, C.; GRAVES, T.K. Interpretation of laboratory tests for canine cushing's syndrome. Top. Companion Anim. Med., v.26, p.98-108, 2011.

HOLDSWORTH, A.; BRADLEY, K.; BIRCH, S. et al. Elastography of the normal canine liver, spleen and kidneys. Vet. Radiol. Ultrasound, v.55, p.620-627, 2014.

MARONEZI, M.C.; FELICIANO, M.A.R.; CRIVELLENTI, L.Z. et al. Acoustic radiation force impulse elastography of the spleen in healthy dogs of different ages. J. Small Anim. Pract., v.56, p.393-397, 2015.
MOGICATO, G.; LAYSSOL-LAMOUR, C.; CONCHOU, F. et al. Ultrasonographic evaluation of the adrenal glands in healthy dogs: repeatability, reproducibility, observer-dependent variability, and the effect of bodyweight, age and sex. Vet. Rec., v.168, p.130-136, 2011.

SLAPA, R.Z; JAKUBOWSKI, W.S.; DOBRUCH-SOBCZAK, K. et al. Standards of ultrasound imaging of the adrenal glands. $J$. Ultrasound, v.15, p.377-387, 2015.

SLAPA, R.Z.; KASPERLIK-ZAŁUSKA, A.A.; MIGDA, B. et al. Shear wave elastography of adrenal masses is feasible and may help to differentiate between solid and cystic lesions - an initial report. Endokrynol Pol., v.65, p.119-124, 2014.

SOULSBY, S.N.; HOLLAND, M.; HUDSON, J.A. et al. Ultrasonographic evaluation of adrenal gland size compared to body weight in normal dogs. Vet. Radiol. Ultrasound, v.56, p.317-326, 2015. 